\title{
METODE PEMAHAMAN HADIS KONTEMPORER (MENURUT MUHAMMAD AL-GAZALI DAN YUSUF AL-QARDAWI)
}

\author{
Fakhrurrozi \\ Program Studi Pendidikan Bahasa Arab STAI As-Sunnah Deli Serdang \\ J1. Medan-Tg. Morawa, Km. 13 G. Darmo, Desa B. Sari, Kec. Tg. Morawa Kab. Deli Serdang \\ qmunib@yahoo.co.id
}

\begin{abstract}
Abstrak: Muhammad al-Gazali dan Yusuf al-Qardawi adalah dua ulama besar kontemporer. Keduanya, telah banyak memberikan kontribusi pemikiran dalam kajian Islam, khususnya dalam memahami teks-teks kesyariahan. Al-Gazali dalam kitabnya as-Sunnah an-Nabawiyah menawarkan empat metode dalam memahami sebuah hadis. Artinya, untuk memahami hadis dengan baik, menurutnya, harus berhadapan secara langsung dengan Alquran, Hadis, fakta sejarah dan kebenaran ilmiyah. Hadis yang bertentangan dengan inti ajaran Alquran menurut beliau langsung tertolak, bahkan beliau terlihat sangat tengas dan berani dalam menghukumi sebuah hadis, tanpa memperpanjang kalam. Sedangkan Yusuf alQardawi, dalam hal ini tampaknya lebih berhati-hati. Menurut al-Qardawi, untuk memahami Hadis Nabi, ada delapan langkah yang bisa dilakukan, yaitu: 1) Memahami Sunnah sesuai petunjuk Alquran, 2) Menghimpun hadis-hadis yang setema, 3) Kompromi atau tarjih terhadap hadis-hadis yang kontradiktif, 4) Memahami hadis sesuai dengan latar belakang, situasi dan kondisi serta tujuannya, 5) Membedakan antara sarana yang berubah-ubah dan tujuan yang tetap, 6) Membedakan antara ungkapan hakiki dan majaz, 7) Membedakan yang gaib dan yang nyata, 8) Memastikan makna kata-kata dalam hadis.
\end{abstract}

Kata Kunci: Metode Pemahaman, Kontemporer

\section{Pendahuluan}

Tidak ada manfaat buku-buku Hadis jika hanya bahan pajangan atau sekedar koleksi perpustakaan. Bagaikan keledai yang dibebani tumpukan kitab Hadis, tapi apa isinya, tidak usah dipertanyakan kepadanya. Di sisi lain,sebuah peradaban yang berkembang jika lari dari nilai-nilai agama, yang telah terangkum dalam Alquran dan Hadis Nabi, itu pun tidak ada artinya. Oleh, karenanya, peradaban dan agama, harus seiring sejalan, bahkan agama itu sendiri adalah sebuah peradaban.

Kehadiran Rasulullah saw., di tengah-tengah kehidupan masyarakat adalah sekaligus membawa tafsiran hidup terhadap nilai-nilai Alquran itu sendiri. Oleh karenanya, ketika 'Aisyah ditanya tentang bagaimana akhlak Nabi saw., maka 
dengan lekas beliau menjawab, akhlaknya adalah Alquran. Artinya, jika ingin melihat bagaimana Alquran itu hidup, bagaimana Alquran itu hadir dalam kehidupan nyata, maka lihatlah kepribadian Rasulullah saw. Sungguh telah ada bagi kamu pada diri Rasulullah itu keteladanan yang baik, bagi siapa pun yang berharap Allah dan negeri akhirat. Oleh karena itu pula, memahami hadis-hadis Nabi merupakan sebuah jalan dalam meneladani petunjuk Alquran.

Pada masa kehidupan Rasul, orang-orang tidak perlu buka kamus, buka referensi, bertanya kesana dan kemari, untuk mendapatkan pemahaman terhadap teks Alquran. Berbeda dengan sekarang, jauhnya jarak antara dua masa, menjadi kendala tersendiri dalam memahami teks-teks agama, yang tertuang dalam Alquran dan Hadis. Selain krisis ekonomi, krisis moral dan krisis keyakinan, krisis pemahaman Hadis juga menjadi problem tersendiri, hari ini.

\section{Pembahasan}

1. Metode Pemahaman Hadis Nabi menurut Muhammad al-Gazali

a. Metode Pemahaman Hadis menurut Muhammad al-Gazali

Melalui bukunya yang berjudul, as-Sunnah an-Nabawiyah baina Ahli alFiqhi wa Ahli al-Hadis, dapat disimpulkan bahwa Muhammad al-Gazali menetapkan empat kriteria dalam memahami Hadis Nabi, yaitu: 1) Perbandingan hadis dengan Alquran, 2) Perbandingan hadis dengan hadis lain, 3) Perbandingan hadis dengan fakta sejarah, 4) Perbandingan hadis dengan kebenaran ilmiah. ${ }^{1}$

Di bagian awal-awal kitabnya, Muhammad al-Gazali mengatakan, ${ }^{2}$

$$
\begin{aligned}
& \text { انظر موقف عائشة رضي الله عنها عندما سمعت حديث إن الميت يعذب ببكاء } \\
& \text { أهله عليه ـ لقد أنكرته وحلفت أن الرسول ما قاله , وقالت - بيانا لرفضها إياه - } \\
& \text { أين منكم قول الله سبحانه " ولا تزر وازرة وزر أخرى " . إها ترد ما يخالف القرآن }
\end{aligned}
$$

${ }^{1}$ Suryadi, Metode Kontemporer Memahami Hadis Nabi Perspektif Muhammad al-Ghazali dan Yusuf al-Qardhawi, (Yogyakarta: Teras, 2008), h. 209.

${ }^{2}$ Muhammad al-Gazali, as-Sunnah an-Nabawiyah baina Ahli al-Fiqhi wa Ahli al-Hadis, (Dar asy-Syuruq, ...), h. 21-23. 


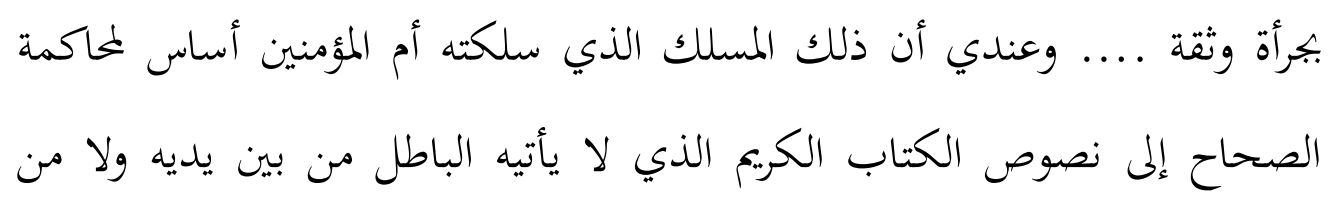

خلفه .

Selanjutnya, melalui contoh-contoh yang akan disajikan berikut, akan terlihat lebih jelas, tentang aplikasi metode pemahaman hadis sebagaimana yang diterapkan oleh Muhammad al-Gazali, dalam kitabnya as-Sunnah anNabawiyah.

b. Penerapan Pemahaman Hadis menurut Muhammad al-Gazali

1) Perbandingan hadis dengan Alquran

Penerapan pemahaman hadis dengan metode ini dilakukan Muhammad al-Gazali secara konsisten, sehingga banyak hadis yang sahih seperti dalam kitab Sahih al-Bukhari dan Muslim yang dianggap daif. Beliau lebih mengutamakan hadis yang sanadnya daif, bila kandungan maknanya sejalan dengan prinsip ajaran Alquran daripada hadis yang sanadnya sahih tetapi kandungan maknanya tidak sejalan dengan inti ajaran Alquran dalam persoalan kemaslahatan dan mua 'malah duniawiyah. ${ }^{3}$

Salah satu contohnya adalah hadis 'Aisyah di atas. Muhammad alGazali berpendapat bahwa dosa yang dilakukan oleh orang hidup tidak mungkin dibebankan kepada orang mati. Pemahaman tentang larangan menangsisi si mayit saat meninggal dengan alasan bahwa hal tersebut hanya akan mendatangkan siksa bagi si mayit, menurutnya, pemahaman seperti itu jelas-jelas salah, karena bertentangan dengan firman Allah:

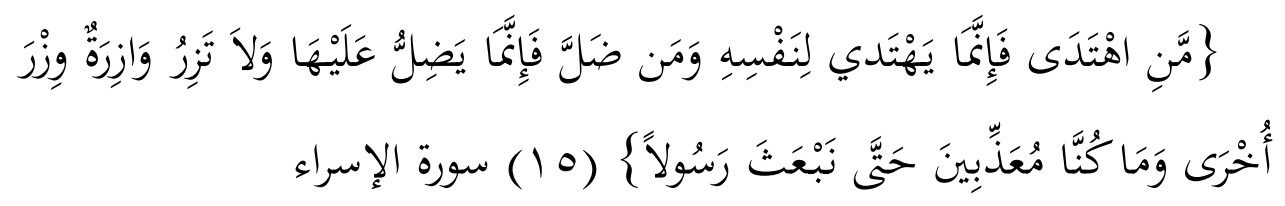

Menurutnya, pemahaman tersebut harus diluruskan, bahwa mayit yang dimaksud dalam hadis itu adalah mayit orang kafir bukan orang mukmin. Hal ini ditekankan oleh 'Aisyah lewat ucapannya:

${ }^{3}$ Suryadi, Metode Kontemporer Memahami Hadis Nabi, h. 84. 


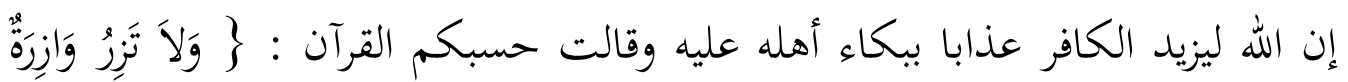<smiles>[Y][Si]#[As]</smiles>

Beliau menambahkan, mungkin saja kemudian orang akan berkata, justru ayat di atas berlaku secara umum, baik bagi orang mukmin maupun bagi orang kafir. Artinya, prinsip keadilan yang tersirat dalam ayat itu berlaku bagi setiap orang. Al-Gazali menjelaskan bahwa menambah siksa terhadap orang kafir justru lebih adil, karena hal itu adalah resiko sekaligus bentuk tanggungjawab atas penyesatan orang lain, sebagaimana firman Allah:

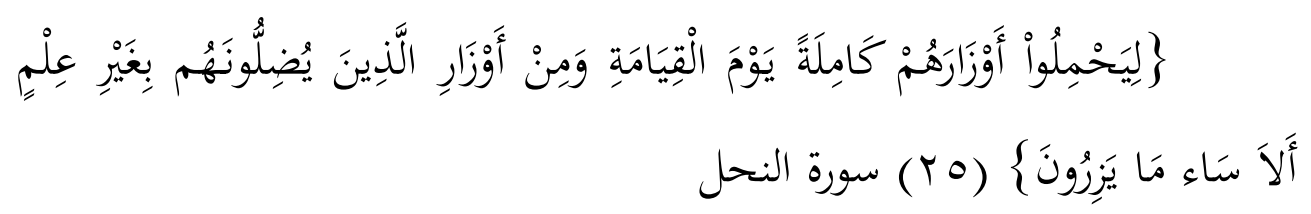

2) Perbandingan hadis dengan hadis lain

Yang dimaksud dengan metode ini ialah, melakukan komparasi antara hadis yang satu dengan hadis yang lain yang setema. Sebelum melakukan istimbat hukum, perlu dilakukan uji coba dengan hadis-hadis lain yang berkaitan. Hal ini dimaksudkan guna mendeteksi bahwa hadis yang dijadikan argument tersebut benar-benar tidak bertentangan dengan hadis mutawatir atau hadis yang lebih kuat. Karena, kalau itu terjadi maka yang dipakai adalah hadis yang lebih kuat derajatnya. ${ }^{4}$ Dalam hal ini, al-Gazali memberikan beberapa contoh antara lain, ${ }^{5}$

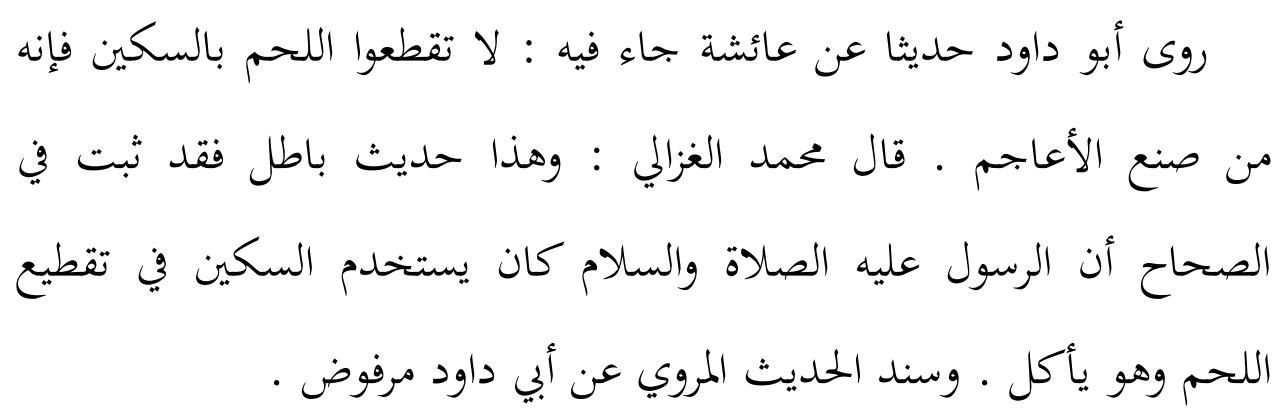

${ }^{4}$ Ibid., h. 85 .

${ }^{5} \mathrm{Al}-$ Gazali, as-Sunnah an-Nabawiyah,h. 103. 
Barangkali hadis yang dimaksud oleh al-Gazali di antaranya adalah hadis riwayat imam al-Bukhari dalam kitab Sahih-nya dengan nada sebagai berikut:

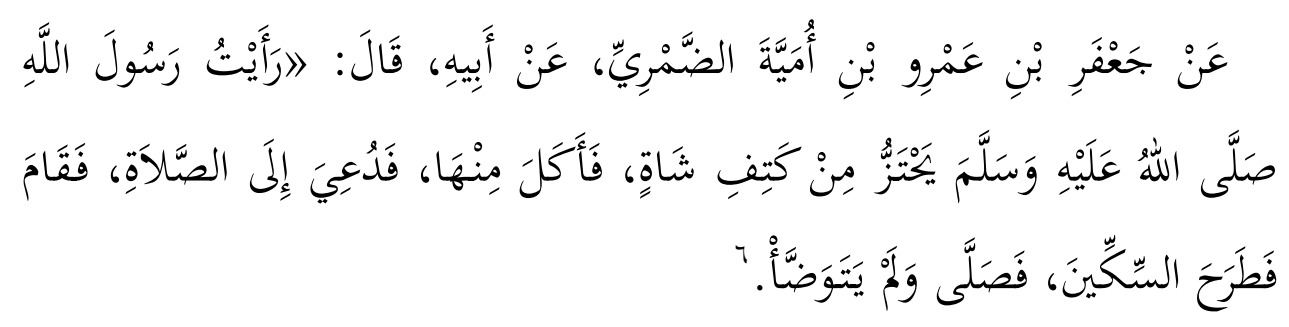

Dari uraian di atas terlihat bahwa untuk memahami hadis dengan baik haruslah melakukan komparasi antara satu riwayat dengan riwayat lain. Lebih jauh dari itu sesungguhnya adalah membandingkan pendapat ulama dalam memahami sebuah hadis.

3) Perbandingan hadis dengan fakta sejarah

Hadis dan sejarah memiliki hubungan sinergis yang saling menguatkan satu sama lain. Adanya kecocokan antara hadis dengan fakta sejarah akan menjadikan hadis memiliki sandaran validitas yang kokoh, sebaliknya apabila terjadi penyimpangan antar keduanya, salah satu diantara keduanya akan diragukan kebenarannya. ${ }^{7}$ Namun demikian, perlu sadari bahwa sejarah itu sendiri pun tidak lepas dari berbagai polemik, itu sebabnya mengapa penting mencantumkan kata fakta dalam hal ini.

Salah satu contoh fakta sejarah dalam hal ini ialah, berkaitan dengan salat tahiyat masjid saat imam berkhutbah. Beliau berpendapat bahwa dalam hal ini pendapat yang benar ialah pendapat Hanafiyah dan Malikiyah, bahkan imam Malik melihat bahwa salatnya tidak sah, bukan cuma sekedar makruh apalagi Sunnah. Al-Gazali mempertanyakan, di mana riwayat tentang anjuran tahiyat masjid di antara lima ratus khutbah Jumat selama sepuluh tahun. Bukankah ulama Hadis selalu antusias mencatat gerak-gerik Rasulullah saw.,lalu di mana seluruh catatan tentang

${ }^{6}$ Muhammad ibn Isma`il Abu 'Abdillah al-Bukhari, al-Jami` al-Musnad as-Sahih alMukhtasar min Umuri Rasulillah wa Sunanihi wa Ayyamihi, Tahkik Muhammad Zuhair, (Dar Tauq an-Najat, 1422 H), jilid. 7, h. 76.

${ }^{7}$ Suryadi, Metode Kontemporer, h. 85. 
khutbah-khutbah tersebut? Kemudian, darilima ratusan khutbah Jumat yang dilaksanakan Rasulullah, apa mungkin hanya satu riwayat saja yang menganjurkan salat tahiyat masjid?

Selain itu, faktanya bahwa isi khutbah-khutbah Nabi saw., adalah lantunan ayat-ayat suci Alquran, seluruh Jemaah harus diam, fokus dan tekun mendengarkan ayat-ayat tersebut, bukan malah sibuk sendiri dengan membaca Alquran atau mengerjakan salat. Menurutnya, perintah salat tahiyat masjid saat berkhutbah itu hanya pengecualian dan khusus pada lelaki itu saja. ${ }^{8}$

Contoh lainnya adalah hadis tentang salat wanita di rumah dan dikamarnya jauh lebih utama dibandingkan salat di masjid Nabawi bersama Rasulullah saw., menurut al-Gazali hal ini bertentangan dengan fakta bahwa Nabi sendiri ternyata membiarkan para wanita salat berjemaah di mesjid bersama beliau saw., apalagi dalam hal ini, ada larangan tentang mencegah para wanita untuk ikut serta salat di mesjid. ${ }^{9}$ Menurut hemat penulis, al-Gazali tidak lah menolak hadis pertama, melainkan mencoba memahaminya dengan cara yang benar.

4) Perbandingan hadis dengan kebenaran ilmiah

Menurut al-Gazali, hadis dan kebenaran ilmiah adalah dua hal yang saling bergandengan. Hadis yang sahih pasti sejalan dengan fakta ilmiah. Bila satu sama lain tidak bisa dikompromikan, pasti salah satunya ada problem. Salah satu contoh yang dikemukakan beliau dalam hal ini ialah hadis tentang perempuan yang terkena jin. Waktu itu, Nabi saw.,menawarkan dua pilihan, sabar kemudian dapat jaminan Surga, atau didoakan agarsembuh. Al-Gazali, dengan keras menolak hadis ini, begitu juga hadis-hadis lain yang berbicara tentang kemasukan jin. Menurutnya, ini tidak lebih dari penyakit kejiwaan, bukan kerasukan. Bagaimanamungkin Nabi saw., tega membiarkan wanita tersebut tersiksa oleh jin terlaknat itu. Padahal Nabi saw., terkenal sebagai sosok yang

${ }^{8} \mathrm{Al}-$ Gazali, as-Sunnah an-Nabawiyah,h. 27.

${ }^{9}$ Ibid., h. 63. 
paling sayang terhadap umatnya. Membiarkan wanita tersebut korban sepanjang hidupnya, sangat bertentangan dengan kepribadian Rasulullah sebagai sosok yang penyayang dan mulia. ${ }^{10}$

2. Metode Pemahaman Hadis Nabi menurut Yusuf al-Qardawi

a. Metode Pemahaman Hadis menurut Yusuf al-Qardawi

Dalam memahami hadis, Yusuf al-Qardawi dalam bukunya yang berjudul, Kaifa Nata`amal Ma`a as-Sunnah an-Nabawiyah, menggunakan delapan kriteria, yaitu:

1) Memahami Sunnah sesuai petunjuk Alquran

2) Menghimpun hadis-hadis yang setema

3) Kompromi atau tarjih terhadap hadis-hadis yang kontradiktif

4) Memahami hadis sesuai dengan latar belakang, situasi dan kondisi serta tujuannya

5) Membedakan antara sarana yang berubah-ubah dantujuan yang tetap

6) Membedakan antara ungkapan hakiki dan majaz

7) Membedakan yang gaib dan yang nyata

8) Memastikan makna kata-kata dalam hadis ${ }^{11}$

b. Penerapan Pemahaman Hadis menurut Yusuf al-Qardawi

Berikut akan dijelaskan lebih rinci tentang bagaimana aplikasi metode pemahaman hadis versi al-Qardawi sebagaimana yang telah disebutkan di atas.

1) Memahami Sunnah sesuai petunjuk Alquran

Menurut al-Qardawi, untuk memahami sebuah hadis dengan benar, terhindar dari penyelewengan atau takwil yang buruk,maka haruslah sesuai dengan bimbinganAlquran. Karena terdapat hubungan yang signifikan antara hadis dengan Alquran. Hadis berfungsi sebagaipenjelas terhadap Alquran. Karenanya, tidak mungkin ada hadis sahih yang bertentangan dengan ayat-ayat Alquran yang bersifat muhkam. Jika itu terjadi, boleh

\footnotetext{
${ }^{10} I b i d .$, h. 123.

${ }^{11}$ Yusuf al-Qardawi, Kaifa Nata `amal Ma`a as-Sunnah an-Nabawiyah, (al-Mansurah: Dar al-Wafa', cet. VI, 1993 M), h. 196.
} 
jadi: 1) hadisnya tidak sahih 2) pemahamannya yang kurang tepat 3)pertentangan itu hanya bersifat dugaantidak hakiki. Oleh karenanya, di akhir pembahasan tentang metode ini, beliau memberi sebuah catatan penting agar tidak salah dalam menggunakan metode ini, sebagaimana kaum muktazilah yang menolak hadis syafaat.

Adabeberapa contoh yang dikemukakan Yusuf al-Qardawi dalam hal ini, di antaranya hadis tentang anjuran mengikutsertakan kaum wanita dalam bermusyawarah walau pun hanya sebatas formalitas.

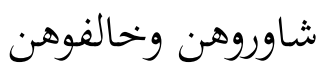

Menurut al-Qardawi, hadis di atas palsu karena jelas-jelas bertentangan dengan konsep Alquran surah al-Baqarah: 233, tentang anjuran bermusyawarah,

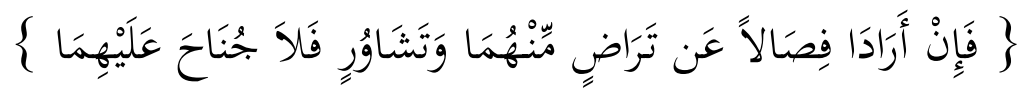

Beliau menambahkan, jika terdapat variasi ulama fikih atau para pensyarah dalam memahami sebuah hadis maka yang paling tepat adalah pendapat yang dikuatkan oleh Alquran. ${ }^{12}$

2) Menghimpun hadis-hadis yang setema

Untukmenghindari kesalahan dalam memahami hadis, perlu mempertimbangkan riwayat lain yaitu dengan caramenghimpun hadishadis yang senada. Hal ini perlu dilakukan mengingat bahwa terkadang sebuah hadis saling mengikat, saling mempertegas dan saling mengkhususkan antara satu sama lain.

Dalam hal ini, al-Qardawi menguraikan contoh sebuah hadis tentang hukum pertanian. Pertama-tama beliau mengemukakan hadis yang mencela orang yang membawa alat pertanian ke rumahnya, setelah itu, ia mengemukakan hadis-hadis yang menunjukkan keutamaan bercocok tanam.

\footnotetext{
${ }^{12}$ Ibid., h. 94.
} 


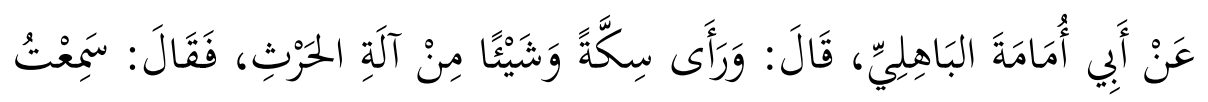

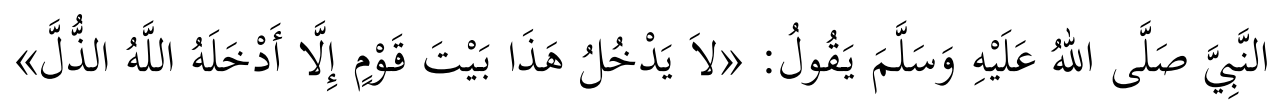
رواه البخاري

عَنْ أَنَسِ بْنِ مَالِكٍ رَضِيَ اللَّهُ عَنْهُ، قَالَ: قَالَ رَسُولُ اللَّهِ صَلَّى اللهُ عَلَّْهِ

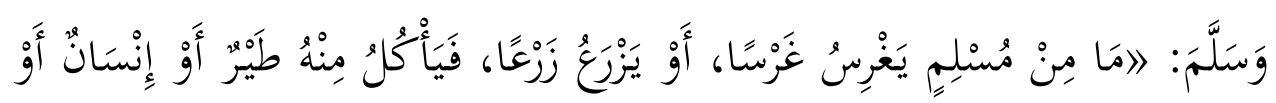

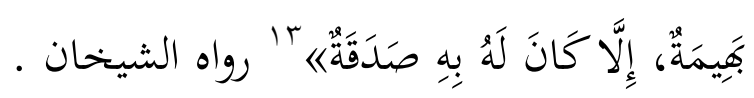

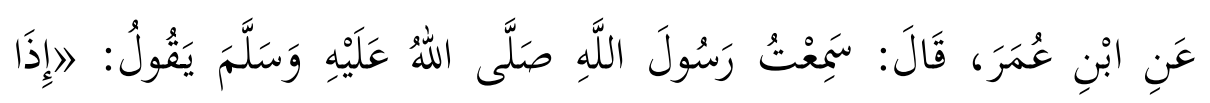

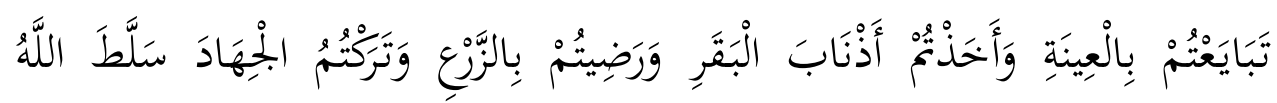

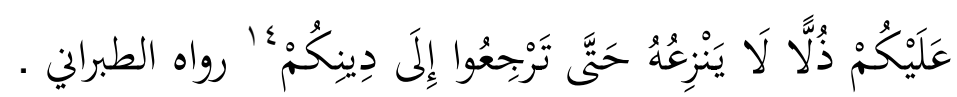

Secara zahir, hadis pertama memang terlihat seolah-olah Rasulullah tidak suka dengan cocok tanam. Akan tetapi setelah menelaah hadis-hadis lain yang berkaitan dengan pertanian, ternyata maknanya tidak seperti itu, justru malah menjadi ladang akhirat bagi pemiliknya jika hasilnya dimanfaatkan makhluk sekitarnya. Adapun alasan kenapa Rasulullah seolah-olah tidak suka dengan cocok tanam, dapat dilihatdari hadis berikutnya. Banyak orang-orang yang lalai dari kewajibannya, akibat terlalu sibuk mengurusi urusan ladangnya. Dengan menghimpun hadishadis terkait, sebagaimana dilakukan di atas, maka akan melahirkan pemahaman yang utuh dan benar terhadap maksud hadis tertentu.

3) Kompromi atau tarjih terhadap hadis-hadis yang kontradiktif

Padadasarnya, tidak adanas-nas syariyangsahih saling kontradiksi. Kebenaran tidak akan mungkin saling bertentangan satu sama lain. Kalau pun ada, menurut al-Qardawi itu hanya luarnya saja, pada hakekatnya tidak demikian. Hadisyang tampak bertentangan dapat diselesaikan dengan

\footnotetext{
${ }^{13}$ Ibid., h. 108-109.

${ }^{14}$ Abu al-Qasim at-Tabrani, Musnad asy-Syamiyyin, Tahkik Hamdi ibn 'Abd al-Majid,
} (Beirut: Muassasah ar-Risalah, 1984 M), jilid. 3, h. 328. 
cara menkompromikan hadis tersebut, jika tidak maka jalan lain adalah melakukan tarjih.

Dalam hal ini, Al-Qardawi memberikan sebuah contoh tentang wanita dilarang melihat laki-laki.

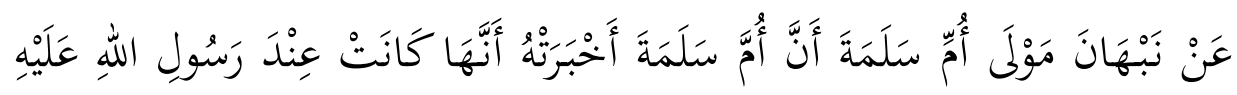

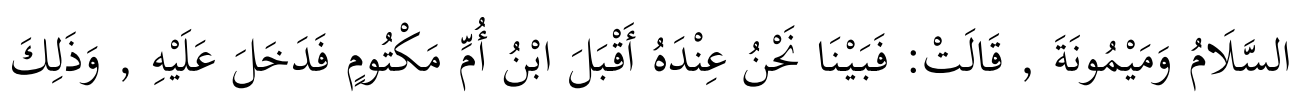

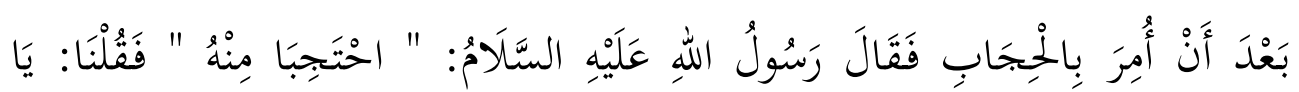

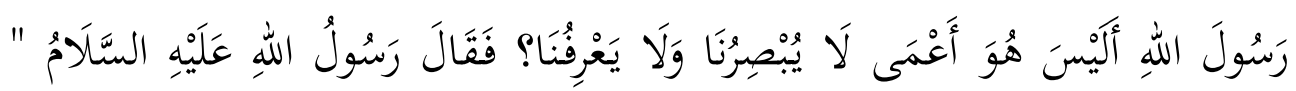

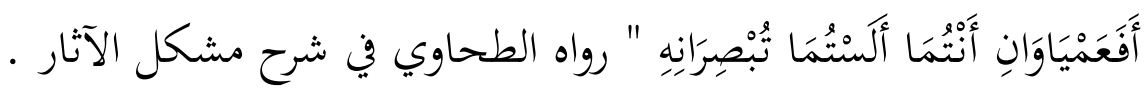

وهذا معارض بما في الصحيحين محا يدل على جواز نظر المرأة إلى الأجنبي •

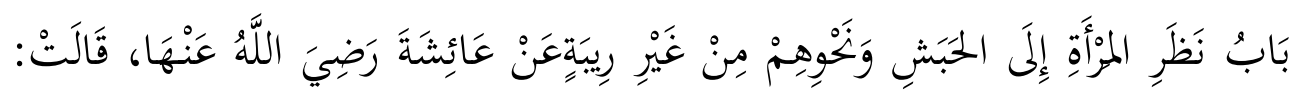

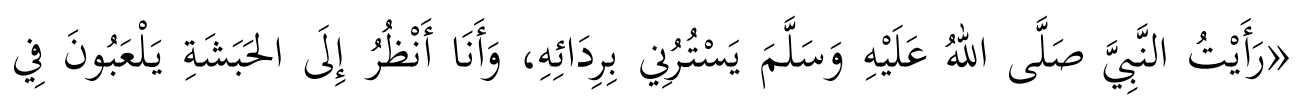

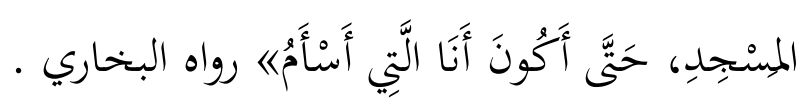

Hadis pertama menunjukkan larangan wanita memandang laki-laki, tetapi hadis kedua justru istri Nabi sendiri yang menonton pertunjukan yang dilakukan orang-orang Habsyah di dalam masjid. Dengan demikian, dapat dikompromikan antara dua hadis yang secara lahir saling bertentangan. Sekedar melihat wajah ajnabi, tidak dilarang, kecuali jika diiringi dengan tatapan nafsu, maka hukum bisa berubah sesuai niat dan ilatnya.

4) Memahami hadis sesuai dengan latarbelakang, situasi dan kondisi serta tujuannya

Memahamihadis Nabi, dapat dilakukan dengan caramemperhatikan latar belakang,ilat, atau melalui kejadian yang menyertainya. Hal ini, mengingat bahwa Nabi itu adalah sosok yang multi fungsi, bisa berperan sebagai pemberi solusi, penyelesai perkaradan seterusnya. 
Dengan mengetahui hal tersebut seseorang dapat melakukan pemahaman atas apa yang bersifat khusus dan yang umum, yang sementara dan abadi. Dengan demikian, menurutnya, apabila kondisi telah berubah dan tidak ada illat lagi, maka hukum yang berkenaan dengan suatu nas akan gugur dengan sendirinya. Hal itu sesuai dengan kaidah, sebuah hukum berlakusesuaiilat-nya. ${ }^{15}$

Contohnya adalah hadis tentang larangan bermukim di perkampungan kaum orang kafir.

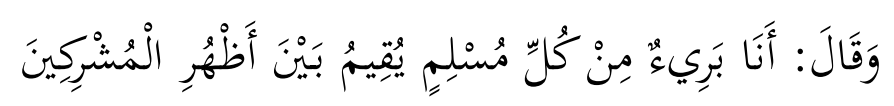

Sekilas, hadis di atas terkesan ekstrem, tidak boleh merantau dan bermukim di negeri orang-orang kafir. Dahulu memang demikian, jaminan keamanan belum ada, karena itu barangsiapa yang terbunuh di negeri orang kafir, maka Rasulullah saw., berlepas diri. Artinya, apa pun yang terjadi, itu di luar tanggungjawab Nabi. Darisejak awal, Nabi sudah kasih aba-aba, jika terjadi apa-apa, resiko ditanggung masing-masing.

Lain halnya dengan sekarang, zaman sudah berubah, orang-orang butuh belajar ke luar negeri, berobat, bekerja, masalah kedutaan, berdagang dan lain sebagainya. Dulu dilarang karena keamanan belum terjamin, antar Islam dan kafir saling perang dan bermusuhan. Ketika hari ini, ilatnya sudah hilang, maka gugur pula hukum yang menyertainya. ${ }^{16}$

5) Membedakan antara sarana yang berubah-ubah dan tujuan yang tetap

Memahamihadis Nabi harus memperhatikan tujuan yang bersifat menetap, dan sarana yang dapat berubah-ubah. Di antara faktor yang menyebabkan terjadinya kesalahan dalam memahami hadis adalah karena mencampuradukkanantara tujuan dan sarana, tanpa memilah-

\footnotetext{
${ }^{15} \mathrm{Al}-\mathrm{Qardawi}$, Kaifa Nata`amal,h. 128.

${ }^{16}$ Ibid., h. 128.
} 
milahnya, atau lebih fokus pada sarana sementara target hadis itu sendiri diabaikan. ${ }^{17}$

Dengan demikian, bila suatu hadis menyebutkan sarana tertentu untuk mencapai tujuan, maka sarana tersebut tidak bersifat mengikat, karena sarana tersebut ada kalanya berubah karena adanya perkembangan zaman. Misalnya hadis tentang siwak. Menurut alQardawi, penyebutan siwak dalam hadis itu, tidak mengikat untuk terus menggunakannya. Targetutamanya adalahagar terjaganya kebersihan dan kesehatan gigi dan mulut. Adapun alat yang digunakan tergantung pada situasi dan kondisinya. Di zaman sekarang, pemakaian sikat dan pasta gigi sama nilainya dengan pemakaian siwak di masa Nabi. $^{18}$

6) Membedakan antara ungkapan hakiki dan majaz

Bahasa Arab kaya dengan kata-kata majaz. Bahkan, penggunaan majaz lebih berkesan di hati dibandingkan kata-kata yang bersifat langsung atau hakiki.Misalnya, hadis tentang ucapan Nabi kepada para istrinya,
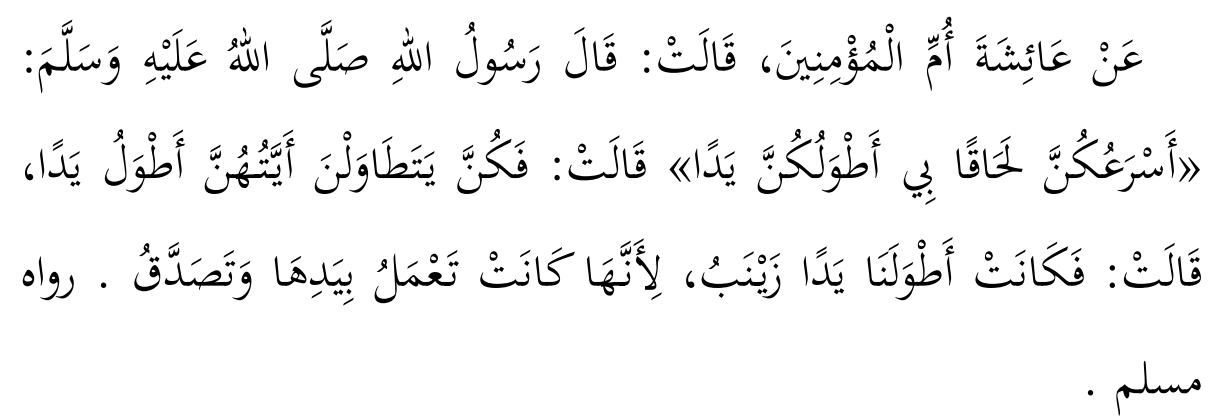

Hadis ini, oleh sebagian istri Nabi difahami secara tekstual, bahkan ada yang mengukur tangannya sendiri. Padahal maksud Nabi bukan makna hakiki, melainkan makna majaz. Setelah Zainab meninggal, baru lah mereka sadar, ternyata yang dimaksud panjang tangan di sini

\footnotetext{
${ }^{17}$ Ibid., h. 139.

${ }^{18}$ Ibid., h. 141.
} 
adalah panjang tangan dalam hal kedermawanan, mudah memberi dan gemar bersedekah. ${ }^{19}$

7) Membedakan yang gaib dan yang nyata

Hadis, tidak hanya berbicara tentang alam nyata, tetapi juga membahas hal-hal yang bersifat gaib. Hadis, berbicara tentang malaikat, jin, setan, iblis, 'Arasy, Kursi, Qalam, Lauh Mahfuz dan lain sebagainya.Tidak bisa dipungkiri, bahwa tidak semua cerita hal gaib hadisnya sahih. Ada yang sahih ada juga yang tidak. Tetapi, pembahasan hanya fokus pada hadishadis sahih saja. Dalam hal ini, menurut al-Qardawi, banyak aliran yang terlalu mudah menolak hadis-hadis alam gaib, meskipun derajatnya sahih, hanya karena tidak masuk akal. Beliau mencontohkan seperti sebagian muktazilah, yang tidak percaya terhadap azab kubur, mizan, rukyatullah dan lain sebagainya. Bahkan hari ini, ada orang yang tidak percaya tentang hadis mutawatir seperti yang tertera pada kitab as-Sahihain,

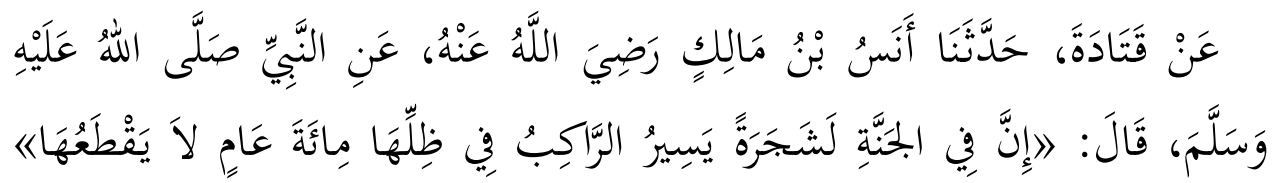

رواه البخاري

Menurut al-Qardawi, kesalahan mendasar yang dilakukan oleh muktazilah dalam hal-hal gaib ialah mengukur alam gaib dengan alam nyata, mengukur akhirat dengan ukuran dunia. Kias seperti itu, adalah kiasfasid, karena setiap alam pasti memiliki hukumnya sendiri. ${ }^{20}$

8) Memastikan makna kata-kata dalam hadis

Hal yang tidak kalah pentingnya dalam memahami hadis ialah memastikan makna asli dari hadis itu sendiri. Terkadang tunjukan makna dari sebuah kata, bergeser dari satu masa ke masa lain, dari satu tempat ke tempat yang lain. Sehingga pemaknaan suatu lafaz di zaman terdahulu tidak sama lagi dengan pemaknaannya di masa kini. Ini yang terkadang membuat pergeseran makna. Contoh sederhananya adalah kata-kata at-

${ }^{19}$ Ibid., h. 156.
${ }^{20}$ Ibid., h. 177.

Jurnal WARAQAT Volume I, No. 1, Januari-Juni 2016 | 13 
taswir. Sekarang, jika disebutkan kata-kata taswir, maka yang terbayang adalah kamera atau foto. Pertanyaannya adalah apa betul yang dimaksudkan Nabi waktu itu sama dengan apa yang difahami oleh orangorang hari ini? Sehingga hukum hadis itu bisa paksakan kepada fotografer hari ini. Jadi, penting sekali mengetahui tunjukan lafaz syar`i, sehingga istinbat hukum yang dihasilkan benar-benar bisa dipertanggungjawabkan.

\section{Penutup}

Dari beberapa uraian di atas terlihat bahwa problematika pemahaman hadis ini merupakan sesuatu yang urgen untuk ditelaah, karena untuk meneladani Nabi, umat Islam dihadapkan dengan berbagai persoalan. Mulai dari menyangkut orisinalitas hadis, metode pengkajian hingga kepada istimbat hukumnya.Dua tokoh di atas tentu belum cukup untuk mewakili seluruh metode pemahaman hadis yang ada, butuh pengkajian yang lebih luas dan mendalam, sehingga dapat diperbandingkan dan diambil mana yang terbaiknya. Perlu dikaji tentang metode pemahaman hadis imam-imam mazhab, para ulama setelah mereka, menampilkan berbagai variasi dan corak ulama kontemporer.

Terkait kedua tokoh di atas, kelihatannya lebih fokus pada kajian matan bukan pada sanad, hanya saja al-Gazali lebih mengandalkanAlquran dibandingkan metode-metode lain, sementara al-Qardawi tidak. Pemikiran keduanya bukan hal yang sama sekali baru. Beberapa kriteria yang ditawarkan keduanya merupakan refleksi terhadap realita masyarakat dan berbagai konsep yang ditawarkan para ulama sebelumnya. Keduanya termasuk pemikir kontekstual, al-Gazali cenderung liberal, sedang al-Qardawi tradisional. Implikasiyang muncul telah mengarah pada upaya pengembangan pemikiran hadis sebagai sesuatu yang positif untuk dikembangkan. Beberapa metode yang ditawarkan minimaldapat membuka mata untukterus menggali nilai-nilai hadis yang relevan dengan konteks saat ini.

\section{Pustaka Acuan}

Al-Bukhari, Muhammad ibn Isma`il Abu 'Abdillah, al-Jami`al-Musnad as-Sahih al-Mukhtasar min Umuri Rasulillah wa Sunanihi wa Ayyamihi, Tahkik Muhammad Zuhair, Dar Tauq an-Najat, $1422 \mathrm{H}$. 
Al-Gazali,Muhammad, as-Sunnah an-Nabawiyah baina Ahli al-Fiqhi wa Ahli alHadis, (Dar asy-Syuruq.

At-Tabrani Abu al-Qasim, Musnad asy-Syamiyyin, Tahkik Hamdi ibn 'Abd alMajid, Beirut: Muassasah ar-Risalah, 1984 M.

Al-Qardawi,Yusuf, Kaifa Nata`amal Ma`a as-Sunnah an-Nabawiyah, alMansurah: Dar al-Wafa', cet. VI, 1993 M.

Suryadi, Metode Kontemporer Memahami Hadis Nabi Perspektif Muhammad alGhazali dan Yusuf al-Qardhawi, Yogyakarta: Teras, 2008. 